\title{
Study on the Risk of Commercial Banks by the Debt-for-Equity Swap
}

\author{
Xiao Wang ${ }^{1}$, Xin-ming Chen ${ }^{2}$, De-yun Zhen ${ }^{1}$, Ke Gao ${ }^{1}$ \\ ${ }^{1}$ The School of Public Finance and Taxation, Central University of Finance and Economics, Beijing, P. R. China \\ ${ }^{2}$ The School of Government, Central University of Finance and Economics, Beijing, P. R. China
}

Email address:

188072767@qq.com (Xiao Wang), 417976918@qq.com (Xin-ming Chen), zhdynk@126.com (De-yun Zhen), gkfly@126.com (Ke Gao)

To cite this article:

Xiao Wang, Xin-ming Chen, De-yun Zhen, Ke Gao. Study on the Risk of Commercial Banks by the Debt-for-Equity Swap. International Journal of Business and Economics Research. Vol. 6, No. 4, 2017, pp. 58-60. doi: 10.11648/j.ijber.20170604.13

Received: June 6, 2017; Accepted: July 2, 2017; Published: July 19, 2017

\begin{abstract}
With China's economy changing into the new normal, the business environment faced by commercial banks has undergone major changes. The real economy is facing many difficulties. The rising rate of non-performing loans has become a business problem which commercial banks have to face. Therefore, in this kind of condition, The debt-for-equity swap seems to be a good recipe for commercial banks to regain their confidence in management. However, the author thinks that the debt-for-equity swap will bring many risks to commercial banks: Financial risk, Liquidity risk, Cash Payment risk and Moral risk. Therefore, if the debt-for-equity swap will be carried out massively, it is not necessarily a good thing for the commercial Banks. So we need to take a cold look at the debt-for-equity swap.
\end{abstract}

Keywords: Debt-for-Equity Swap, Commercial Banks, Financial Risk, Liquidity Risk, Cash Payment Risk, Moral Risk

\section{Introduction}

Recently, In China, The debt-for-equity swap has become a buzzword in the financial field. For commercial banks facing economic pains, the resurgence of the debt-for-equity swap undoubtly brings the dawn. However, From the operational model of commercial banks, the debt-for-equity swap will bring many risks to commercial banks: Financial risk, Liquidity risk, Cash Payment risk and Moral risk. Therefore, If the debt-for-equity swap will be carried out massively, it is not necessarily a good thing for the commercial Banks.

\section{Discussion}

With china's economy changing into the new normal, which is economic growth from high-speed to medium high speed, the real economy is facing many difficulties. [1] As the unreasonable structure and the production side of the mismatch, they have caused business turnover problems, resulting in a decline in the corporate profits. The direct result increases the corporate loan repayment pressure, so that the current non-performing assets ratio at the commercial banks is on the rise. By the end of 2015, the non-performing loans at the domestic commercial banks had amounted to 1.2744 trillion yuan, increasing 431.8 billion yuan compared with last year, an increase of more than $50 \%$ and 16 consecutive quarter rebound. The non-performing loan ratio reached $1.67 \%$ increasing by 0.08 percentage points and 10 consecutive quarters up. With the increase of the non-performing loans ratio at the commercial banks, the profitability of the banks falls into an unprecedented crisis. The embarrassing situation for the four state-owned commercial banks was that their profit growth reached less than $10 \%$ in 2015 ( Table 1). How to break the current dilemma and get steady profitability is becoming the most important issue in the new normal economic environment to be considered. In March, 2016, The state council premier Li keqiang in Boao Forum for Asia on a speech pointed out that we would use the way of marketlization to promote the debt for equity swap and explore using the debt for equity swap to lower the corporate leverage. At the same time. October, 2016, The State Council issue < Opinions on actively and steadily reducing the leverage ratio of enterprises $>$. In this opinion, we must adhere to the proactive fiscal policy and prudent monetary policy orientation. In a market-oriented and legalized way, through the promotion of mergers and acquisitions, and improve the modern enterprise system. 
Strengthening self discipline, revitalizing the stock assets, optimizing debt structure, Orderly transfering market bank debt, which lay the foundation for sustained and healthy economic development. After being silent all these years, the debt for equity swap was illuminated once again, the commercial banks begin to be eager for it, as if seeing the predawn light. It is thought that the debt for equity swap has become an effective solution to non-performing loans from commercial banks. Can the debt for equity swap really bring hope for the commercial banks?

Table 1. 2015 State-owned bank income statement.

\begin{tabular}{lllll}
\hline BANK & Business income (Billion yuan) & Year-on-year growth (\%) & Net profit (Billion yuan) & Year-on-year growth (\%) \\
\hline ICBC & 6976.47 & 5.88 & 2771.31 & 0.48 \\
CCB & 6051.97 & 6.09 & 2281.45 & 0.14 \\
ABC & 5361.68 & 2.94 & 1805.82 & 0.62 \\
BC & 4743.21 & 3.94 & 1708.45 & 0.74 \\
\hline
\end{tabular}

From: China Banking Regulatory Commission

For the answer to the issue, it seems right in the short term, the commercial banks can turn the corporate debt equity into the stock equity. The commercial banks become the corporate' $\mathrm{s}$ shareholders from the creditors. It seems that the commercial banks would like to see, especially for the ordinary staffs who will be the dominant force to promote the debt for equity swap. [2]

First, in the bank leader's view, the bank leadership is using the tenure rotation policy. The bank leader in office hopes to take advantage of the debt for equity swap to solve the non-performing assets, which helps not only to reduce the non-performing assets from the book, but also to improve asset quality in form. [3] Undoubtedly, it is helpful to enhance their own KPI indicator for performance evaluation. It is considered that the debt for equity swap is a good recipe for the bank leader's short revenue or long-term job promotion. [4]

Second, for the bank employees, the non-performing loans not only reduce their income but also make them suffer pain from asset collection. In psychology, if getting rid of the pain in the short term, the person will gain a sense of security. Therefore, the debt for equity swap provides timely help for the bank employees beyond doubt. [5]

Last, For the entire banking industry, with the interest rate market step by step, the days when Chinese commercial banks made money only on interest margins were over. At the same time, the commercial banks are facing the downward operating environment. Therefore, The growth of profit margins has become a major task for commercial banks. The implementation of the debt to equity swap is undoubtedly an important help to improve the profitability of commercial banks. Consequently, for the industry as a whole, that's what everyone would like to see.

However, the author believe that it is the key for the issue to know the operation mode of the commercial banks. Under normal conditions, the normal operation of the commercial banks must be based on funds. The commercial banks utilize the way of tie-in term difference to offer loans and earn interest margin. Banks must guarantee enough fund liquidity during this period. The amount of funds must meet regular payment. Fundamentally, the debt for equity swap will affect the normal operation of commercial banks. In the long term, this approach is the use of space for time. If you carry out a large-scale debt for equity swap will bring some risks.

\subsection{Financial Risk}

The debt for equity swap changed the form of bank loans. The form of bank loans change the company's debt into the company's equity. Original bank loans are expected to get the loan principal and interest recovery, along with the flow of funds to obtain a fixed interest income. Bank loans have certain expectations of the recovery of funds in time and profitability. Now, the debt for equity swap change bank loans to investment. [6] In the long term, this investment for banks will make banks face more risks and uncertainties. Equity is to obtain income through corporate returns. The yield of the returns and return time is difficult to be forecasted. The companies which are carried out the debt for equity swap, have problems in the current management, liquidity and so on. The possibility of such enterprises is not profitable in the short term. These companies need to go through a long-term governance. At the same time, the banks as corporate shareholders, in terms of time and energy or the professional degree, do not have the management capacity of enterprises. [7] Therefore, from a long-term point of view, if the debt for equity swap is performed, the recovery of bank funds faces the greater risk.

\subsection{Liquidity Risk}

Term difference is an important means of commercial bank management assets and liabilities. Banks issuing loans to a variety of different maturities, it is expected that the normal recovery of principal in order to ensure liquidity, normal interest is charged to ensure profits. [8] However, the debt for equity swap will affect the bank's liquidity. This is mainly reflected in two aspects. First, bank loans turn into equity, which would delay the funds back time, and increase pressure of bank assets and liabilities management and bank liquidity. Second, debt investment relative to equity investment will face more risks and uncertainties, if poor management of the enterprise will make the bank funds unable to quit for a long time and cause the commercial Banks to hold passively the equity of the enterprise. [9] If the enterprise management cause deterioration and even bankruptcy, the commercial Banks will be permanent loss of liquidity.

\subsection{Cash Payment Risk}

Deposits and loans are the two most important businesses of 
the commercial banks. During this period, the commercial banks also have sufficient liquidity to meet daily cash requirements. Recovery of normal bank loans on schedule is an important way to ensure cash adequate liquidity. However, the emergence of debt for equity swap make the bank funds faced with risks, resulting in tight bank liquidity, so it will inevitably affect the daily cash payment of commercial bank. If carried out the large-scale debt for equity swap, the banks will bear the pressure of bank run, which is bound to cause systemic financial risk. [10]

\subsection{Moral Risk}

Lending staffs have to use all their resources to find high quality company and confirm that there are reasonable financial gaps in the enterprises. In such way, bank staffs designs a produce of lending productions which are fit to the enterprises' need of Liquidities. In this process, the debt for equity swap will lead to moral hazard. First, in the enterprises' view, the debt for equity swap is the baseline of continued operation for the enterprises. Companies which meet the conditions of the debt can ignore their own characteristics and needs of business management cycle, raise loans on a large scale to expand the enterprises. If the companies face business risk and only need to change debt into equity, which will transfer part of the losses to the bank. Second, from the bank staff side of view, in order to complete the daily performance indicators, bank staffs do not investigate the company with due diligence. If the company has problems, the bank will choose equity instead of debt to reduce non-performing loans. [11] In this case, the company's risk has little influence in the bank. [12]

\section{Conclusion}

In the current economic situation, the debt for equity swap is the best way to resolve the non-performing loan ratio of the commercial banks. The role of the debt for equity swap to play in will need to improve a series of supporting measures. However, Commercial banks will have serious consequences if they treat debt equity swap as the only way to dispose of non-performing assets. If carried out massively, it is not necessarily a good thing for the commercial banks. Therefore, at present, the commercial banks face the benefits of debt to equity swap, which need to calm down and think about the drawbacks. Only in this way can we maximize the role of debt equity swap in dealing with non-performing assets of commercial banks.

\section{References}

[1] Zhou xiao chuan. Several issues concerning debt to equity swap [J]. Comparison of economic and social systems, 1999(11): 1-9.

[2] Li Yang. China national balance sheet 2015: Leverage adjustment and risk management $[\mathrm{M}]$. Chinese Social Science Press, 2015.

[3] Du Jin. Debt to equity swap call for renewed: Comb AMC debt to equity swap business [N]. Financial Times, 2016-03-28.

[4] Zhang Xiao Mei. Experience of foreign financial Asset Management Co and its reference significance to China [J]. Accounting in Shanghai, 2001(9): 14-16.

[5] Wu You Chang, Zhao Xiao. Debt equity swap: Theory and policy analysis based on corporate governance structure $[\mathrm{J}]$. Economic research, 2000(2): 26-33.

[6] Lou Fei Peng. The historical experience and suggestions for the implementation of bad loans and debt to equity swap in commercial banks [J]. Southwest finance, 2016(5).

[7] Li Li. How can commercial banks participate in making conversion. [J]. Chinese Rural Finance, 2016(5).

[8] Liu Lei. Research on the legal issues of debt to equity swap in the disposal of non-performing assets of banks [J]. Journal of Jilin TV and Radio University, 2016(5).

[9] Chen Li Wen, Tong Zi Juan, Ye Li. New financing model for small and medium sized scientific and technological enterprises: Theoretical analysis based on portfolio framework [J]. Financial Development Research, 2016(4).

[10] Wu Lin Chang. Reconsideration of bankruptcy isolation in the asset securitization trust model [J]. Finance and economy, 2016(4)

[11] Zhang Kun, Ou Ming Gang. Evaluation report on competitiveness of city commercial banks in 2015: Urban commercial bank transformation and development hot spot under new normal [J]. Banker, 2015(10).

[12] Zhou Wan Fu. Rational view and implementation of debt equity swap [J]. China Finance. 2016(8). 